\title{
Hérnia Diafragmática Pós-Traumática: Limitações da Ventilação Não Invasiva
}

\section{Post-Traumatic Diaphragmatic Hernia: Limitations of Non-Invasive Ventilation}

\begin{abstract}
Daniela Marta RODRIGUES ${ }^{1}$, Juliana Maria SILVA² ${ }^{2}$ Nuno Lacerda PRÍNCIPE ${ }^{3}$
\end{abstract}
Acta Med Port 2017 Dec;30(12):890-890 - https://doi.org/10.20344/amp.9254

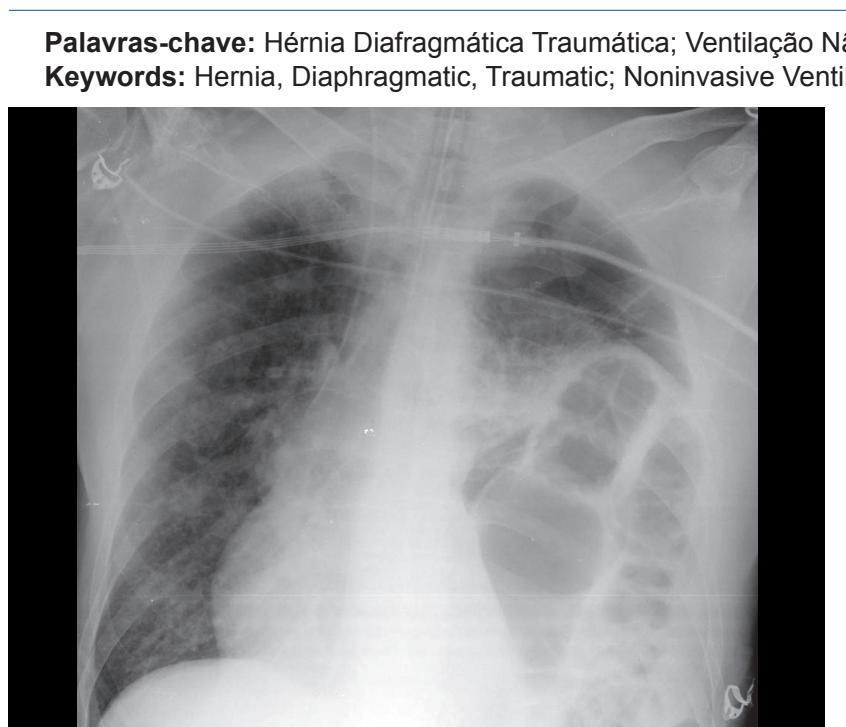

Figura 1 - Radiografia de tórax (incidência póstero-anterior): níveis hidro-aéreos nos andares médio e inferior do hemitórax esquerdo

Idoso com antecedentes de alcoolismo, tabagismo, doença pulmonar obstrutiva crónica e hérnia diafragmática pós-traumática com recusa prévia de correção cirúrgica. Recorreu ao serviço de urgência por dispneia agravada com dois dias de evolução. À admissão apresentava polipneia, obnubilação e acidemia respiratória grave. Pelo facto da ventilação não invasiva (VNI) instituída precocemente não ter tido sucesso, iniciou-se ventilação invasiva. A radiografia torácica (Fig. 1) revelou níveis hidro-aéreos nos andares médio e inferior do hemitórax esquerdo e a tomografia computorizada (Fig. 2) uma hérnia diafragmática contendo o estômago, ângulo cólico esquerdo e cauda pancreática, com vólvulo gástrico não complicado. Foi então definido um plano de descompressão gástrica com sonda e correção cirúrgica diferida. Apesar de evolução inicial favorável, o doente acabaria por falecer no Serviço de Medicina Intensiva no contexto de múltiplas intercorrências.

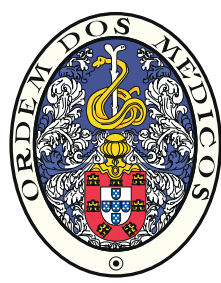

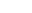

